\title{
TECHNOLOGY BASED SUPERVISION: SEARCHING AN EFFECTIVE SCHOOL SUPERVISION MODEL FOR REMOTE/DISADVANTAGE AREA IN INDONESIA
}

\author{
IKHFAN HARIS ${ }^{1}$, YURNI RAHMAN ${ }^{2}$, ZULAECHA NGIU ${ }^{3}$, HARIS PANAI ${ }^{4}$ \& LIA NURHAYATI ${ }^{5}$ \\ ${ }^{1,4}$ Faculty of Education, Universitas Negeri Gorontalo, Indonesia \\ ${ }^{2,5}$ Faculty of Education, Universitas Muhammadiyah Gorontalo, Indonesia \\ ${ }^{3}$ Faculty of Social Sciences, Universitas Negeri Gorontalo, Indonesia
}

\begin{abstract}
The study aims to explore the using of technology in school supervision practices, as a strategy for searching an effective school supervision model for remote/disadvantage area in Indonesia. This paper is dealing with the using of technology to support effective school supervision practices in remote/disadvantage area. The research approach employed in this study was literature review. The review assessed country reports and various literature evaluations of school supervision from some countries in Asia an Australia. The paper will be focused on the approaches and strategies of school supervision that have been applied by other countries that may be applicable for school supervision in remote/disadvantage area in Indonesia. The result of review of the policies and practices of school supervision from several countries it became swiftly apparent that many are on the same learning journey as Indonesia and that Indonesian supervision policies and guidelines were comparable with many of these countries. The potential of information and communications technology in all forms of education including in school supervision practices has been well demonstrated. The study has examined and provided information on approaches to school supervision for remote/disadvantaged and border/outlying areas utilized in other countries and it may be adopted or adapted to the unique environment in the remote/disadvantaged areas in Indonesia.

KEYWORDS: Technology, School, Supervision, Remote, Disadvantage \& Area
\end{abstract}

Received: Jun 08, 2020; Accepted: Jun 28, 2020; Published: Sep 12, 2020; Paper Id.: IJMPERDJUN20201189

\section{INTRODUCTION}

Education supervision is a strategic process that assures quality education for all students. With the support of the school supervisor, the school principal, teachers and community ensure students develop to their full potential (Grek et.al, 2013; Agih, 2015; Hashim, 2020). The school supervisor is part of the overall educational personnel that is strategically positioned in national education quality improvement (Sudjana et.al, 2011; Gray, 2014). To achieve its main task, the school supervisor must be equipped with personal competencies such as managerial and academic supervision, education evaluation, research and development and social capabilities (Armana et.al, 2016; Kemendikbud, 2010; Sidho, 2002). Through the process of formative supervision, educational organizations including schools commit to contributing to bringing the nation to its ideology through the achievement of the eight (8) education national standards. This is as a part of Indonesian's vision on the education field (Rosser, 2018; Haris et.al, 2018).

In Indonesia's remote/disadvantaged areas, which know as ' $3 \mathrm{~T}$ ' special regions may only receive one supervision visit per year - if at all. In order to reduce disparity between ' $3 \mathrm{~T}$ ' areas and the rest of Indonesia is to be achieved, the school supervisor function (as one key input to better schools) needs to be performing much more effectively than it is currently. ' $3 \mathrm{~T}$ ' special regions are part of priority areas categorized as regions which are 
underdeveloped, remote, and in outer/frontier (daerah 3T). 3T is abbreviated from Tertinggal, Terdepan, dan Terluar; literally means; the Frontier, Outermost and Disadvantaged Area. Areas classified as remote (terpencil), disadvantaged (tertinggal) and on Indonesia's borders or outlying (terdepan/terluar); as per Presidential Regulation No. $131 / 2015$.

A region to be deemed as an under-developed region is determined by the human resource condition in that region (Presidential Regulation Number 131 of 2015 on Stipulating Under-Developed Regions, Article 2 Paragraph 1). It is commonly accepted that human resource quality is mainly determined by the education quality in that region (Luke, 2012; Vnoučková et.al, 2016; Akareem \& Hossain, Syed 2016). This shows that improving education quality in the underdeveloped regions must become the state and nation integrated development priority, according to the National Priority Agenda, especially number 3, which is: "To develop Indonesia from the suburban areas by strengthening regions and villages within the country" and National Priority Agenda number 5, which is "To Improve Indonesian individuals and community life quality".

The problem of education in remote/disadvantaged or ' $3 \mathrm{~T}$ ' special regions are more complex than that in other advantage areas, among them shown by the data of school accessibility by student or disparity/education equality (BPS, 2016; Haris et.al, 2018). These data is presenting as follows:

Table 1: Scope of School Distance in Special Regions (3T) in Indonesia

\begin{tabular}{|c|c|c|c|}
\hline & \multicolumn{3}{|c|}{\begin{tabular}{|l|l|} 
Remote/Isolated Regions & Urban Regions \\
\end{tabular}} \\
\hline \multicolumn{4}{|c|}{ Average Distance to School (km) } \\
\hline \begin{tabular}{|l|l|} 
Elementary school (SD) & \\
\end{tabular} & 9,75 & 2,43 & 5,78 \\
\hline Junior secondary school (SMP) & 12,28 & 4,11 & 7,17 \\
\hline Senior secondary school (SMA) & 20,85 & 7,59 & 12,57 \\
\hline \multicolumn{4}{|c|}{\begin{tabular}{|c|} 
Number of Education Infrastructure \\
\end{tabular}} \\
\hline SD & 34,471 & 96,618 & 131,089 \\
\hline SMP & 7,296 & 13,578 & 20,875 \\
\hline SMA & 1,954 & 4,068 & 6,022 \\
\hline
\end{tabular}

Aside from accessibility, they also face problems about low education quality compared to other regions in general.

Table 2: Education Equality in Special Regions

\begin{tabular}{|c|c|c|c|}
\hline Education Indicator & \multicolumn{3}{|c|}{ Remote/Isolated Regions|Urban Regions|Nationa } \\
\hline \multicolumn{4}{|c|}{ Participation in Education } \\
\hline Average length of school & 6,96 & 8,44 & 7,93 \\
\hline Literacy rate & 86,8 & 95,13 & 92,99 \\
\hline \multicolumn{4}{|l|}{ Source: MoNE, 2016} \\
\hline
\end{tabular}

A review conducted by Indonesian Ministry of Education (MoNE) in 2015 regarding school supervisors in special regions (3T) or remote/disadvantaged areas identified several issues, among others: (1) lack of capacity building for units of education by the school supervisor; (2) lack of school supervisor visits to target schools due to geographical and infrastructure obstacles, such as the surrounding terrain, distant school location, and limited transportation; and (3) lack of operational funds to implement supervisory tasks in the special regions. In addition, the review also identified causes for supervision problems in the special regions, such as (1) number of school supervisors is less compared to the number of target schools which will supervise by supervisor; (2) the education background and work experience of supervisor do not match the main tasks of a school supervisor; (3) the local Provincial/ District Education Office offers not enough 
opportunity to train and build the competency of school supervisors; (4) lack of operational funding for school supervision; (5) lack of monitoring on Minimum Service Standard for the implementation of school supervision by the central and local government; (6) lack of community/ school committee involvement in supporting the school supervision implemented in schools; (7) the distance between target school and school supervisor's office and (8) the limited transportation facilities for school supervision (MoNE, 2016).

Since the educational conditions in the special region that is mostly restricted, a model should be created and developed for implementing supervision in special regions in order to support the school supervisor in completing or performing its tasks. To assist the school supervisor in conducting his/her main task effectively and efficiently, it should be provided a guideline for supervision implementation in the ' $3 \mathrm{~T}$ ' special regions or remote/disadvantaged areas. In order to gain more insight into the characteristics of school supervising practice in remote/rural areas and it will be use as a basis for establishing effective supervision model for school supervision in special regions (3T) in Indonesia; some question is still open and need to be answered. These question, such as: (1) from a national and international perspective, how does supervision practice in remote/rural areas compare with urban school supervision practices?; (2) what contextual factors influenced the supervisory practices in special areas (3T) in Indonesia?; (3) what challenges and difficulties do supervisors encounter in their supervisory functions when dealing with supervision in special areas (3T) in Indonesia?; (4) what are principal problems dealing with supervision and support services are presently facing in term of organizational structure; overall management and daily function?; (5) how does central and local government invest in school supervision in special areas (3T) in Indonesia?; (6) what strategies are critical to developing effective school supervision in special areas (3T) in Indonesia?; (7) what is the effective supervision model that could be implemented and appropriate for school supervision in special regions (3T) in Indonesia?

\section{Roles and Implementation of School Supervision: The Context}

School supervisors have an important role to play in supporting principals and teachers to improve the quality of education delivered in schools, and in strengthening the capacity of principals and teachers to deliver on this goal (Kaufman, 2010; Enaigbe, 2010; Kholid, 2019). The role of the supervisor is a critical role for MoEC as it delivers a number of system and school priorities to improve student outcomes.

In Indonesia's remote/disadvantaged areas extremes of geography and lower levels of financial and human resource capacity are preventing effective supervision occurring. Schools in remote and in the outermost areas may only receive one supervision visit per year - if at all. If the aim to reduce disparity between remote/disadvantaged areas and the rest of Indonesia is to be achieved, the school supervisor function (as one key input to better schools) needs to be performing much more effectively than it is currently (Hallencreutz, 2012; Ani, 2007).

Education supervision is a strategic process that assures quality education for all students (Marzano, 2011). With the support of the School Supervisor, the school principal, teachers and community ensure students develop to their full potential to become faithful religious citizens who believe in God Almighty (Ihsanuddin, 2015). Students graduating will be healthy, educated, skilled, creative, and independent citizens who are democratic, accountable, and possess noble intentions that embrace the cultural systems of their tribe (Law No. 20/2003, Article 3). Through the process of formative supervision, educational organizations including schools commit to contributing to bringing the nation to its ideology through the achievement of the eight education national standards. 
School Supervisors are responsible for reviewing principal and teacher performance (Glickman, et.al, 2001; Coe, et.al, 2014), student academic and wellbeing outcomes, curriculum implementation approaches, financial and administrative management, maintenance of buildings, the health of the learning and work environment, and adequate resourcing of the school. They will evaluate and make judgments referencing MoEC policy and direction, the National Education Standards, the National Education Minimum Standards, and the National Principal and Teacher Standards. They will use the MoEC guidelines for Principal and Teacher Appraisal in making judgments about overall performance, as well as the principal and individual teacher's impact on school improvement and student improvement annually.

The School Supervisor will analyze data and review evidence to ensure their judgments and those of the school principal, teachers and community members are transparent and in line with public accountability principles (No. 21/2010 Article 188 point $1 \& 2$ ). With the support of the community they will provide constructive feedback and formal recommendations to the appropriate local governing bodies and Divisions (Law No. 20/2013 Sisdiknas Article 66). The School Supervisor is responsible for providing leadership and guidance to the school principal, teachers and community members, and delivering professional learning programs in regards to MoEC and school priorities.

The Principal is responsible for leading the academic program and management of the school. They liaise with the School Supervisor, their staff and community to ensure rigour, transparency and quality school and student outcomes (Permenpan RB 21/2010; Permendikbud 143/2014; Joint Regulation by Mendiknas and Head of BKN 01/111/PB/2011, No. 6/2011; Perpres 131/2015, Permendikbud 34/2012). They are responsible for school supervision program plans, implementation and evaluation. Supervision is conducted collaboratively through face to face meetings, observation and the through the gathering of evidence to inform judgement.

The Principal is responsible for leading the management of the school through the development of the school plan with reference to the Minimum Service Standards, National Education Standards, and the National Principal and Teacher Standards.

\section{Schools Supervision Practices in Indonesia}

School supervision leads to improved teaching and learning via two intermediate mechanisms: (1) Setting expectations for schools and stakeholders. Supervision criteria and procedures influence schools and their stakeholders to align their views/beliefs and expectations of what constitute good education to the standards in the supervision framework. Schools and stakeholders are expected to use these standards in their daily management of, and or activities in the school, and (2) Schools and stakeholders accepting supervision feedback. Schools align their education to the standards they failed to meet during the latest supervision visit as outlined in supervision feedback (Ehren et.al, 2013). Schools use supervision feedback when conducting self-evaluations and when taking improvement actions. Likewise, stakeholders are expected to use the supervision feedback (as publicly reported) to take actions that will motivate the school to improve.

These two intermediate mechanisms can improve the self-evaluations of schools; building schools' capacity to improve that in turn will lead to more effective teaching and learning conditions. Likewise, improvement actions will (when successfully implemented) lead to more effective school and teaching conditions. In turn this process, should, logically, result in higher student achievement (Luginbuhl et al, 2009; Ünal, 2013).

A review conducted by MoNE in 2015 regarding school supervisors in remote/disadvantage areas identified several issues, among others: (1) lack of capacity building for units of education by the school supervisor; (2) lack of 
school supervisor visits to target schools due to geographical and infrastructure obstacles, such as the surrounding terrain, distant school location, and limited transportation; and (3) lack of operational funds to implement supervisory tasks in the special regions. In addition, the review also identified causes for supervision problems in the special regions, such as (1) number of school supervisors is less compared to the number of target schools which will supervise by supervisor; (2) the education background and work experience of supervisor do not match the main tasks of a school supervisor; (3) the local Provincial/ District Education Office offers not enough opportunity to train and build the competency of school supervisors; (4) lack of operational funding for school supervision; (5) lack of monitoring on Minimum Service Standard for the implementation of school supervision by the central and local government; (6) lack of community/ school committee involvement in supporting the school supervision implemented in schools; (7) the distance between target school and school supervisor's office, and (8) the limited transportation facilities for school supervision (MoNE, 2015).

\section{Technology Approaches for School Supervision}

Professional learning is imperative in all professional organizations and vital in schools where school and student improvement policies and programs continue to be updated (Hawkins and Shohet, 2007). Remote principals and staff meet the daily challenge of not only being isolated geographically but also having minimal access to regular electricity, and communication and information technologies.

The professional learning approach acknowledges the planning to date by the Special Regions Committee. This approach recognize the geographical isolation of the Special Regions as well as the significant budget challenges faced by the School Supervisor, the distances to schools and the transport challenges, and the lack of infrastructure to support a quality supervision process. They emphasize that ICT in education has a multiplier effect throughout the education system, by enhancing learning and providing students with new sets of skills; by reaching students with poor or no access (especially those in rural and remote regions); by facilitating and improving the training of teachers; and by minimizing costs associated with the delivery of traditional instruction.

Beyond sub-regional differences, the internal digital divide of developing countries has also increased significantly as urban centers quickly adopt ICT while it remains out of reach for rural and remote regions. Bearing these caveats in mind, ICT in education in Asia can be viewed from two very different perspectives. The first reflects a development discourse that stresses the role of ICT in eliminating the digital divide by reaching the unreached and providing support to those who cannot access essential infrastructure, trained teachers and other quality educational resources (Range et.al, 2012). The second perspective adheres to an e-learning paradigm and is a response to the emerging knowledge society where ways of teaching and learning are evolving at a rapid pace to foster learner-centric educational environments, which encourage collaboration, knowledge creation and knowledge sharing (Stelmach, 2018). While countries are admittedly at different stages of integrating ICT in education, ultimately both perspectives will be increasingly relevant for countries in Asia. In counties that face such issues the following solutions have been implemented:

- Philippines: Microsoft have a project for rural areas where content and curriculum can be downloaded to a Windows phone and then played through a television or other device and reloaded when educators travel to a larger city

- Indonesia: Microsoft has partnered with MoEC on the E-Sabak project for student textbooks. This currently 
includes using OneNote to access information anywhere, anytime and load to One-Drive when there is an opportunity to do so. This same project would enable professional learning programs to be loaded regularly to a school or teacher laptop and smart phone. Updates could be completed each time the Supervisor meets with the Principal allowing new material to be shared every three to four months.

- In Indonesia, Zenius has developed an online platform for teacher professional development. The platform provides a mix of free and paid content:

- In Australia apps are loaded to smart phones that allow exemplars of: (1) teacher and Principal standards; (2) curriculum implementation; (3) quality teaching processes and (4) new policy implementations e.g. child safety

- In Australia, the Solomon Islands, Tonga and Indonesia television such as TV Edukasi is used to distribute professional content via satellite. TV-Edukasi (TV-e) broadcasts animated units of instruction focused on the primary curriculum. The e-dukasi.net Web site offers forums, recommended Web sites, learning activities and exam-preparation resources for Indonesian secondary students. This tool could also be used to facilitate content for principals and teachers.

- In Australia, the Solomon Islands, Tonga, Fiji and Vanuatu radio is used to distribute professional content

- In many countries PD on a Stick (USB) has been used and this could be transferred regularly by the School Supervisor or by mail or by drone.

The field of supervision activities, which could be covered by this professional learning approach, is both managerial and academic supervision. In order to implement this professional learning approaches require some prerequisites. These requirements are: (1) Adequate support electricity from various sources; (2) provide facilities of laptops for school supervisors and principals; (3) mobile phones that use various solutions, e.g. 3G, 4G, Satellite and its variations, radio; (4) a data backup solution. Cloud technologies should be considered; (5) the use of drones (to be considered for transport of materials and equipment) and (6) access to the internet whether at school or at a location identified for school use on a routine basis - i.e. through an agreed calendar of non-face to face supervision.

\section{ICT Approach for Data Collection and Analysis for School Improvement}

In Indonesia data is currently collected through 31 instruments along with observations collected whilst at the school. The Committee has already identified that these data collections are entered generally on paper by the school and the Supervisor. The Supervisor then spends an extraordinary amount of time manually analysing data into a report that is lodged with the local governing authority (Kaden \& Healy, 2014). The Committee noted that this report is retained by the local governing authority, is not shared with MoEC and is not acted upon. The report has no impact and is a redundant exercise (Suryahadi \& Sambodho, 2013).

In Australia and in a number of countries such data is loaded into a database that as its end point provides a single point of truth for the student, the principal, the teacher, and the supervisor. That means that any data collected about an individual is attributed back to that individual. This in time provides a cumulative record about each student, principal, teacher, and supervisor and provides agreed evidence on which to make judgements.

Technically data mining tools can be loaded as apps to the principal's laptop and downloaded when they come to the meetings twice a year. Data can also be uploaded when the School Supervisor visits the school. There is a backup 
server in the school. Cloud technologies should be considered. Alternatively are: (a) if data loads are required more regularly Drones can pick up and drop off memory sticks and materials up to 2 kilograms, or it can be sent by mail or via other school personnel visiting district centres, and (b) data can be stored offline until online capability is available as mentioned in point 1 .

This kind of transmission is seen as more helpful as in areas such as Papua where the Telkom's (Indonesian telecommunication) transmission capacity for the entire province is 20 Mbps - compared, say, with a typical OECD residential connection of $8 \mathrm{Mbps}$ (2010 data). As a result of these factors, data transfer speeds on the Internet are slow and of poor quality at all times, compared to international and even national norms, and in many instances make Web access impossible (OECD, 2013). By passing the network for such things as data transmission is seen as sensible enabling small opportunities for internet use to be used for other communication priorities.

In order to send information and reports to and from remote villages to district and/ or national offices, and to collect, store and manage them, several alternatives were considered, particularly for areas with no or unstable telecommunication signal. At the beginning of the design, the use of the following interconnectivity and devices were considered according to the following priority: (1) in villages where there are Wi-Fi/ 3G signal, transfer of information and report to be managed using mobile-phone; (2) where there is telecommunication signal, transfer of information in SMS to be managed using mobile phone; (3) where there is no telecommunication signal, transfer to be conducted through Single Side Band (SSB) radio or other locally utilized telecommunication; (4) at the worst case scenario, sub-district facilitators to collect the information through USB, compile it in his/her laptop and send the information when they find the connection, and (5) at the very remote area there are option to provide portable and Fixed Satellite.

\section{Approach by Using Offsite Meetings with Principals}

In developing country, like in Indonesia it is usual that the school year starts with the School Supervisor meeting with their school principals together at an agreed site for 2-3 days. This could be at the district education office, school cluster, or another agreed location. During this time new policy and practices are discussed, professional development is completed together, technologies are updated, data collections and evidence gathering timelines are established for the year, and individual meetings are completed as part of the Principal Appraisal process. This meeting time provides quality input for the first face to face school based meeting.

These meetings could be held twice a year to: (1) provide a network for principals in which to share practice; (2) disseminate Indonesian MoEC programs and policies; (3) fulfil supervision requirements particularly in regards to the National Education Standards and the Principal and Teacher Standards; (4) complete professional capacity building exercises coach principal supervisory practices establish formats for calendared online/offline meetings (e.g. for coaching, providing advice) when they return to school.

Beside approach of offsite meetings with principals, some supervisors in Indonesia have on their own initiative established e-supervision platforms to enable more frequent communication and guidance for schools under their supervision (Guntoro et.al, 2016; O'Neil, \& Boyce, 2018; Lee et.al, 2013; G Habibi et.al, 2020; Hariyati, 2019; Rugaiyah, 2016; Amiruddin, 2018).

\section{CONCLUSIONS}

This paper present some examples of school supervision models used in other countries that could adapt and/or adopt to 
improve the effectiveness of school supervision in the Indonesian'3T' special regions or remote and disadvantaged schools. The paper has considered a range of national and international examples which using ICT to support and improve the school supervision practice. The paper assessed country reports and various literature evaluations of school supervision from Australia, Bangladesh, the Philippines, the Solomon Islands, Togo, Fiji, Sri Lanka, Zanzibar and Vanuatu as well as Indonesia.

In reviewing the policies and practices from other countries it became swiftly apparent that many are on the same learning journey as Indonesia and that Indonesian supervision policies and guidelines were comparable with many of these countries. The potential of Information and Communications Technology in all forms of education including in school supervision practices has been well demonstrated.

What is significant to note in searching an effective school supervision model for '3T' special regions or remote/disadvantage area by using technology based supervision in Indonesia is that the Ministry of Education and Culture (MoEC) of Indonesia and other Indonesian Ministries between them have many of the solutions required to achieve the MoEC's vision to adequately support schools in $3 \mathrm{~T}$ areas. Some of the solutions sit in the Ministry of Defense, some in the Ministry of Information and Communication Technology, and many of the solutions sit in MoEC itself as pilots or past projects. With some alignment of programs and innovations, and with the introduction of extensive use of solar power to run laptops, phones, and other ICT devices, drones to connect schools with schools, and schools with local governing agencies, MoEC could be recognized as a world leader in the creating of a whole of system-connected learning community.

\section{REFERENCES}

1. Agih, A. Allen. (2015). Effective School Management and Supervision: Imperative for Quality Education Service Delivery. African Research Review, 9(3): 62-74. http://dx.doi.org/10.4314/afrrev.v9i3.6

2. Akareem, Husain Salilul and Hossain, Syed Shahadat. (2016). Determinants of education quality: what makes students' perception different? Open Review of Educational Research, 3(1): 52-67. https://doi.org/10.1080/23265507.2016.1155167

3. Amiruddin. (2018). Urgensi Pengembangan Supervisi Elektronik Berbasis Website Bagi Pengawas Pendidikan Agama Islam Di Lingkungan Kementerian Agama Kabupaten Sumenep. Jurnal Kariman, 6(02): 171-181.

4. Ani, C.I. (2007). Dynamics of school supervision. Enugu: Cheston Books

5. Armana, Syamsul Bachri, Thalibb, and Darman Manda. (2016). The effect of school supervisors competence and school principals competence on work motivation and performance of Junior High School teachers in Maros Regency, Indonesia. International Journal of Environmental \& Science Education, 11(15): 7309-7317

6. Badan Pusat Statistik (BPS). (2016). Statistik Indonesia 2016-Statistical Yearbook of Indonesia 2016. Jakarta Badan Pusat Statistik (BPS).

7. Bangladesh (2013). Master Plan for Information and Communication Technology in Education (2012 - 2021). Dhaka: Ministry of Education.

8. Broadband Commission. (2013). Technology, broadband and education: Advancing the education for all agenda. Paris: UNESCO/ITU.

9. Coe, R. and Aloisi, C. and Higgins, S. and Major, L.E. (2014). What makes great teaching? Review of the underpinning research, Project Report. Sutton Trust, London. 
10. Ehren, M., Altrichter, H., McNamara G. \& O'Hara J. (2013). Impact of school inspections on teaching and learningdescribing assumptions on causal mechanisms in six European countries. Educational Assessment, Evaluation and Accountability, 25(1): 3-43. https://doi.org/10.1007/s11092-012-9156-4

11. Enaigbe, P. (2010). Strategies for Improving Supervisory Skills for Effective Primary Education in Nigeria. Edo Journal of Counselling, 2(2): 235-244. https://doi.org/doi:10.4314/ejc.v2i2.60864

12. Gray, A. (2014). Supporting school improvement. The role of inspectorates across Europe. A report from the Standing International Conference of Inspectorates. SICI.

13. G Habibi, M Mandasari, K Rukun and Hadiyanto. (2020). E-Supervision Using Web: Elementary School Teachers' Reaction. Global Conferences Series: Sciences and Technology (GCSST), Volume 3, 2020. The 1st International Conference on Education, Sciences and Technology, DOI: https://doi.org/10.32698/tech3230.

14. Glickman, C. D., Gordon, S. P. \& Ross-Gordon, J. M. (2001). Supervision and Instructional Leadership. Needhan Heights. MA: Allyn and Bacon.

15. Grek, Sotiria., Lawn, Martin., Ozga, Jenny., \& Segerholm, Christina. (2013). Governing by inspection? European inspectorates and the creation of a European education policy space. Comparative Education, 49(4): 486-502. https://doi.org/10.1080/03050068.2013.787697

16. Guntoro, David, Totok Sumaryanto F., Achmad Rifai RC. (2016). Pengembangan Model Supervisi Akademik Berbantuan ESupervision Berbasis. Educational Management, 5(2): 122-128.

17. Hallencreutz, J. (2012). Under the Skin of Change. Meanings, Models and Management. Lulea University of Technology.

18. Haris, Ikhfan; Fory A. Naway; Wiwy T. Pulukadang; Hiroko Takeshita and Inero V. Ancho. (2018a): School Supervision Practices in the Indonesian Education System; Perspectives and Challenges. Journal of Social Studies Education Research, 9(2): 366-387. https://doi.org/10.17499/jsser.17724

19. Haris, I., A. Naway, F., \& Triyanty Pulukadang, W. (2018b). Review of Effective School Supervision Practice in Remote/Disadvantaged Area: A National and International Perspective. Proceedings of the 1st International Conference on Early Childhood and Primary Education (ECPE 2018). https://doi.org/10.2991/ecpe-18.201

20. Hariri, H., Monypenny, R., Pridaux, M. (2012). Principalship in an Indonesian school context: can principal decision-making styles significantly predict teacher job satisfaction? School Leadership \& Management, 32(5): 453-471. https://doi.org/10.1080/13632434.2012.723617

21. Hariyati, Puspaningati Nunuk. (2019). Pengembangan Model Virtual Peer Supervision Berbasis Website Handini. Inspirasi Manajemen Pendidikan, 7(3): 114-122.

22. Hashim, A. (2020). Collegial Supervisory Practice in Malaysian Public Schools: Evidence from Secondary School Teachers. International Journal of Psychosocial Rehabilitation, 24(5), 2439-2453. https://doi.org/10.37200/ijpr/v24i5/pr201942

23. Hawkins, Peter and Shohet, Robin. (2006). Supervision in the Helping professions. Open University Press.

24. Ihsanuddin, Ahmad. (2015). Implementasi Supervisi Pengawas PAI Dalam Meningkatkan Kompetensi Pedagogik Guru PAI SD Di Kecamatan Berbah Sleman. [Master Thesis]. Institut Agama Islam Negeri (IAIN) Surakarta

25. Ismail, Bruno. (2014). Supervisi akademik pengawas sekolah dalam meningkatkan kualitas pembelajaran di daerah Terdepan, Terluar, dan Tertinggal (3T) (Studi multisitus pada UPTD Kecamatan Elar dan UPTD Kecamatan Borong, Kabupaten Manggarai Timur. [Master Thesis]. Pasca Sarjana. Universitas Negeri Malang. Malang. 
26. Kaden, U. I., Patterson, P. P., \& Healy, J. (2014). Updating the Role of Rural Supervision: Perspectives from Alaska. Journal of Education and Training Studies, 2(3): 33-43. http://dx.doi.org/10.11114/jets.v2i3.364

27. Kaufman, J. (2010). Contemporary issues in supervision. In. E.G., Crespi, T.D., dan Riccio, C.A. (2010). Handbook of education, training, and supervision of school psychologists in school and community. USA: Taylor and Francis Group.

28. Kementrian Pendidikan Nasional. (2010). Pedoman Pelatihan Penguatan Kemampuan Pengawas Sekolah, Kompetensi Supervisi Akademik, Direktorat Tenaga Kependidikan, Direktorat Jenderal, Peningkatan Mutu Pendidik dan Tenaga Kependidikan, Jakarta.

29. Kholid, Kholid. (2019). Principal's Strategies and Approaches to Perform Effective Academic Supervision. Proceedings Article published 2019 in Proceedings of the Proceeding of the 2nd International Conference Education Culture and Technology, ICONECT 2019 https://doi.org/10.4108/eai.20-8-2019.2288126.

30. Lee, J., Lapira, E., Bagheri, B. and Kao, H.A. (2013) Recent Advances and Trends in Predictive Manufacturing Systems in Big Data Environment. Manufacturing Letters, 1(1): 38-41. https://doi.org/10.1016/j.mfglet.2013.09.005

31. Luginbuhl, R. et al. (2009). Do school inspections improve primary school performance?, Educational. Evaluation and Policy Analysis, 31(3): 221-237. https://doi.org/10.3102\%2F0162373709338315

32. Marzano, R. J. (2011). Effective supervision: Supporting the art and science of teaching. Alexandria. Association for Supervision and Curriculum Development.

33. Ministry of National Education (MoNE). (2013). Regulation of Ministry of National Education on Managing of Special Services of Education. Ministry of National Education, Jakarta.

34. Ministry of National Education (MoNE). (2016). Guideline for school supervision in special regions. Directorate for Basic and Secondary Education and Personnel Development, Directorate General for Teacher and Education Personnel, Jakarta.

35. NSW Department of Education (2016). Rural and Distance Education. http://www.schools.nsw.edu.au/rde/distanceedu/

36. O'Neil, K., \& Boyce, B. A. (2018). Improving Teacher Effectiveness in Physical Education Teacher Education Through FieldBased Supervision. The Physical Educator, 75(5): 835-849. https://doi.org/10.18666/TPE-2018-V75-I5-7739

37. OECD (2013). Synergies for Better Learning: An International Perspective on Evaluation and Assessment, OECD Reviews of Evaluation and Assessment in Education. OECD Publishing, Paris, http://dx.doi.org/10.1787/9789264190658-en

38. Partnership on Measuring ICT for Development (2011). Measuring the WSIS Targets: A Statistical Framework. Geneva. International Telecommunication Union (ITU).

39. Pedro, Francesc (2012). Trusting the unknown: The effects of technology use in education. In D. Soumitra and B. BilbaoOsorio (Eds.). The Global Information Technology Report 2012: Living in a Hyperconnected World. Geneva: World Economic Forum and INSEAD.

40. Peraturan Bersama Menteri Pendidikan Nasional dan Kepala Badan Kepegawaian Negara Nomor 01/III/PB/2011, Nomor 6 Tahun 2011 tentang Petunjuk Pelaksanaan Jabatan Fungsional Pengawas Sekolah dan Angka Kreditnya. Jakarta. Departemen Pendidikan Nasional Republik Indonesia

41. Permenpan RB Nomor 143 tahun 2014 tentang Petunjuk Teknis Pelaksanaan Jabatan Fungsional Pengawas Sekolah dan Angka Kreditnya. Jakarta. Departemen Pendidikan dan Kebudayaan Republik Indonesia

42. Philippines (2005). Five-Year Information and Communication Technology for Education Strategic Plan (DeptED ICT4E strategic plan). Manila: Department of Education. 
43. Range, B. G., Young, S., \& Hvidston, D. (2012). Teacher perceptions about observation conferences: what do teachers think about their formative supervision in one US school district? School Leadership \& Management, 33(1), 61-77. http://dx.doi.org/10.1080/13632434.2012.724670

44. Rosser, Andrew. (2018). Beyond access: Making Indonesia 's education system work. Lowy Institute for International Policy. Lowy Institute

45. Rugaiyah. (2016). Pengembangan Model Supervisi Klinis Berbasis Informasi Dan Teknologi. Cakrawala Pendidikan, 35(3): 421-431. https://doi.org/10.21831/cp.v35i3.10429

46. Santiago, P., Donaldson, G., Herman, J., \& Shewbridge, C. (2011). OECD Reviews of Evaluation and Assessment in Education. Australia. OECD Publishing.

47. Stelmach, Bonnie. L. (2018). A Synthesis of International Rural Education Issues and Responses. The Rural Educator, 32(2): 32-42. https://doi.org/10.35608/ruraled.v32i2.432

48. Sidho, K.S. (2002). School organization and administration. New Delhi: Sterling Publishing Limited.

49. Sofo, F., Fitzgerald R., Jawas, U. (2012). Instructional leadership in Indonesian school reform: overcoming the problems to move forward. School Leadership and Management, 32(5): 503-522. https://doi.org/10.1080/13632434.2012.723616

50. Sudjana, Nana. (2011). Supervisi Pendidikan: Konsep dan Aplikasinya bagi Pengawas Sekolah. Bekasi. Binamitra Publishing

51. Suhardan, H .Dadang. (2006). Supervisi Bantuan Profesional. Jakarta. Mutiara Ilmu.

52. Surya, Priadi. (2011). Profesionalisasi Pengawas Pendidikan dalam Konteks Otonomi Daerah. Jurnal Aspirasi, 2(2): (177190.

53. Suryahadi, A. and P. Sambodho (2013). Assessment of Policies to Improve Teacher Quality and Reduce Teacher Absenteeism. Jakarta, Indonesia: SMERU Research Institute.

54. Sutoyo, Arif Rahman, Irsan. (2017). Needs Assessment of Senior High School (SMA) Supervisors of Jambi Province. IOSR Journal of Research \& Method in Education, 7(5): 80, https://doi.org/10.9790/7388-0705028083

55. Syahbani. (2010). Analisis Kinerja Pengawas Sekolah Dasar dalam Meningkatkan Kualitas Pendidikan di Kota Dumai. [Doctoral Dissertation]. Unpublished. Program Pascasarjana Universitas Islam Negeri. Sultan Syarif Kasim Riau. Pekanbaru

56. The Education Sector Analytical and Capacity Development Partnership (ACDP). (2016). Selection of Supervisors tend to be haphazard. https://acdpindonesia.wordpress.com/2016/08/04/selection-of-supervisors-tend-to-be-haphazard/.

57. Ünal, Ali. (2013). Development and validation of supervisory behavior description scale. Educational Research and Reviews, 8(2): 69-76. https://doi.org/10.5897/ERR12.188

58. Vnoučková, l., Urbancová, H., Smolová, H., \& Šmejkalová, J. (2016). Students’ Evaluation Of Education Quality In Human Resource Management Area: Case of Private Czech University. Journal on Efficiency and Responsibility in Education and Science, 9(2), 45-51. https://doi.org/10.7160/eriesj.2016.090203

59. World Bank (2010). Information and Communication Technology for Education in India and South Asia (Volume 1), Extend summary. Washington.D.C.: InfoDev/ Price Water House Coopers.

60. Zeng, H, R. Huang, Y. Zhao and J. Zhang. (2012). ICT and ODL in education for rural development: Current situation and good practices in China. Beijing. UNESCO International Research and Training Centre for Rural Education (INRULED)/ Beijing Normal University, R\&D Center for Knowledge Engineering (BNU-KSEI). 
